\title{
Detection of Chlorophyll-a Front and Its Relation to Skipjack Tuna Catches in Makassar Strait
}

\author{
Andi Risda Fitrianti Abudarda*, Mukti Zainuddin**, Safruddin** \\ *Postgraduate student of Fisheries Sciences, Faculty of Marine Science and Fisheries, Hasanuddin University, \\ Makassar, Indonesia \\ **Faculty of Marine Science and Fisheries, Hasanuddin University, Makassar, Indonesia
}

DOI: 10.29322/IJSRP.11.07.2021.p11560

http://dx.doi.org/10.29322/IJSRP.11.07.2021.p11560

\begin{abstract}
The purpose of this study is to detect chlorophyll-a front by using the Single Image Edge Detection (SIED) method and analyze the influence of the closest distance of chlorophyll-a front to the skipjack tuna catches. This study was conducted from June to August 2019. Data collecting was conducted by using survey method by following fishing operations in two research areas namely Barru Regency and Pinrang Regency, South Sulawesi, which is the representation of the fishing base area of skipjack tuna fishing in Makassar Strait. We collected skipjack tuna catches data and fishing ground positions (longitude and latitude). We used chlorophyll-a imagery data which was downloaded from https://oceancolor.gsfc.nasa.gov/. The results showed that chlorophyll-a front was detected in every observation month and more detected in offshore of the southern part of Makassar Strait. Based on GAM analysis, there is a relationship of the closest chlorophyll-a front distance from the catch point where the skipjack tuna catches is relatively higher at a distance of $15-20 \mathrm{~km}$ from the nearest chlorophyll-a front distance. This research is dedicated to being used as a reference for skipjack tuna resources management in Makassar Strait.
\end{abstract}

Keywords: Skipjack, Chlorophyll-a Front, SIED

\section{INTRODUCTION}

$\mathrm{M}$ assar Strait is known as one of the fertile waters in eastern Indonesia. This is due to the flow of the water mass from the Pacific Ocean that passes through Makassar Strait to the Indian Ocean known as the Indonesian Throughflow (ITF) [1]. Makassar Strait is a part of the circulation of global currents that carry abundant natural resources of small and large pelagic fish, such as skipjack tuna.

Skipjack tuna (Katsuwonus pelamis) is a large pelagic fish resource that is widely exploited by fishermen in Makassar Strait using purse seine. Skipjack tuna is one of the pelagic fish that has a wide migration both horizontally and vertically. The distribution of skipjack is largely influenced by oceanographic conditions, such as sea surface temperature, chlorophyll-a concentration, front and upwelling [2, 3].

The front can be understood as a marker of the boundary of the waters between two different types of water characteristics [4]. Chlorophyll-a front is an indicator that can be used in determining the fishing ground that is also related to the availability of food sources in the waters. The concentration of chlorophyll-a or phytoplankton will determine the amount of primary productivity of the waters which will then be related to the production of catch, especially skipjack. The formation of potential fishing ground of skipjack tuna in the transitional season is related to the preference of environmental factors as well as the presence of front zones, shelf-break $500 \mathrm{~m}$, and upwelling in Bone Bay, Indonesia [5].

The purpose of this study is to detect chlorophyll-a front with the method of Single Image Edge Detection (SIED) as an indication of potential skipjack fishing ground and to analyze the closest distance relationship between chlorophyll-a front to skipjack tuna catch. This research is dedicated to be used as a reference for skipjack tuna fisheries management, especially in Makassar Strait.

\section{MATERIALS AND METHODS}

This research was conducted from June to August 2019, taking locations in Barru regency and Pinrang Regency, South Sulawesi. Data analysis have done at Marine Fisheries and Geospatial Information Laboratory, Faculty of Marine Science and Fisheries, Hasanuddin University.

a. Fishery data

Data obtained include fishing position (latitude and longitude) and skipjack tuna catch data in the number of skipjack and effort (fishing set) by following the purse seine operations in the study area.

b. Satellite remote sensing data 
Satellite remote sensing data set were compiled for sea surface temperature (SST) and chlorophyll-a were downloaded from the NASA Ocean Color website (http://oceancolor.gsfc.nasa.gov/). We used monthly temporal data from June to August 2019 with $4 \mathrm{~km}$ of longitude and latitude spatial resolution.

c. Single Image Edge Detection (SIED)

SIED (Single Image Edge Detection) is one of the automatic methods of thermal front identification [6]. In remote sensing, this method is included in edge detection.

Input data used for front detection process, namely chlorophyll-a data from operational team processing or automatic processing results. The algorithm used is Single Image Edge Detection (SIED). If the image data is hdf (hierarchical data format) with floating data type, then to be applied to SIED toolbox in ArcGIS then the data type should be changed from floating to an integer with truncation. Chlorophyll-a data input in the automatic front detection process must have integer data format. The process of data preparation and front detection is automated.

d. Generalized Additive Model (GAM)

Monthly data of chlorophyll-a concentrations were obtained from satellite imagery then conducted further testing with GAM. The statistical model used is the Generalized Additive Model (GAM) with R language software program (version 3.3.2). GAM is a nonlinear model, usually used to understand the interrelationship between variables observed through the identification of a range of positively influential values. $\mu$ i response variable (number of skipjack catch in tail units) and predictor variable (front distances) that can be formulated like the following equation.

$\mathrm{g}(\mu \mathrm{i})=\alpha .+\mathrm{s} 1$ (chlorophyll-a front distance) $+\varepsilon$

where: $\mathrm{g}=$ spline smooth function, $\mu \mathrm{i}=$ response variable,$\alpha-=$ coefficient of constants, $\mathrm{sn}=$ smoothing function of predictor variables, and $\varepsilon=$ standard error.

GAM modeling is done using the mgcv package contained in the $\mathrm{R}$ language program (version 3.3.2). GAM modeling is done using gaussian distribution and identity link function. The response variable is skipjack tuna catch, while the predictor variable is the front distance.

\section{RESULT AND DISCUSSION}

Chlorophyll-a satellite imagery data from June to August 2019 showed that the concentration of chlorophyll-a in Makassar Strait is dominant in the range of $0.10-0.38 \mathrm{mg} / \mathrm{m}^{3}$ (Figure 1). Chlorophyll-a is higher in areas near the coastal water ranging from $1.03-1.99$ $\mathrm{mg} / \mathrm{m}^{3}$, while the concentration of chlorophyll-a is low in offshore areas in the range of $0.10-0.57 \mathrm{mg} / \mathrm{m}^{3}$. During the months of observation, skipjack tuna catch was conducted in the range of $0.10-1.02 \mathrm{mg} / \mathrm{m}^{3}$. This is in line with the result of the preference of chlorophyll-a concentration to skipjack tuna is in the range of $0.10-0.20 \mathrm{mg} / \mathrm{m}^{3}$ [7]. Another study showed that the area of skipjack tuna catching is well developed and associated with chlorophyll-a values range of $0.18-0.28 \mathrm{mg} / \mathrm{m}^{3}$ [8].
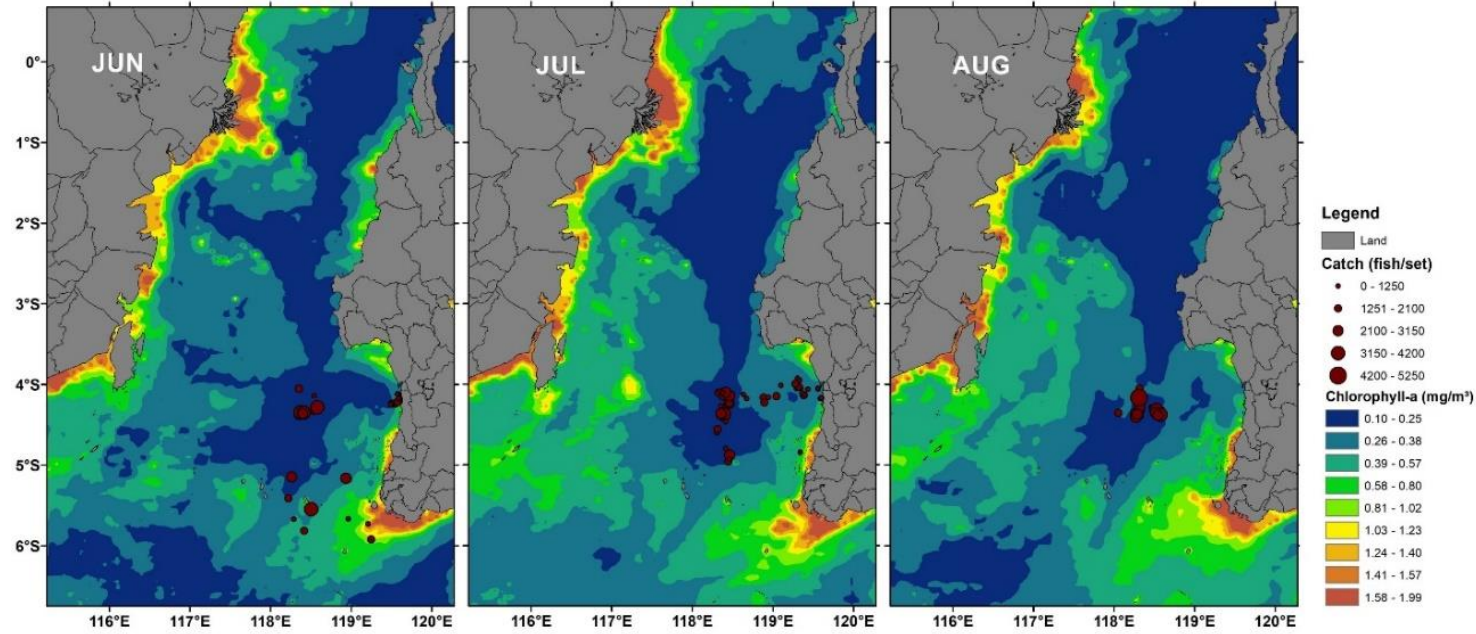

Figure 1. Spatial distribution of skipjack tuna catches with chlorophyll-a from June to August 2019 in Makassar Strait. 

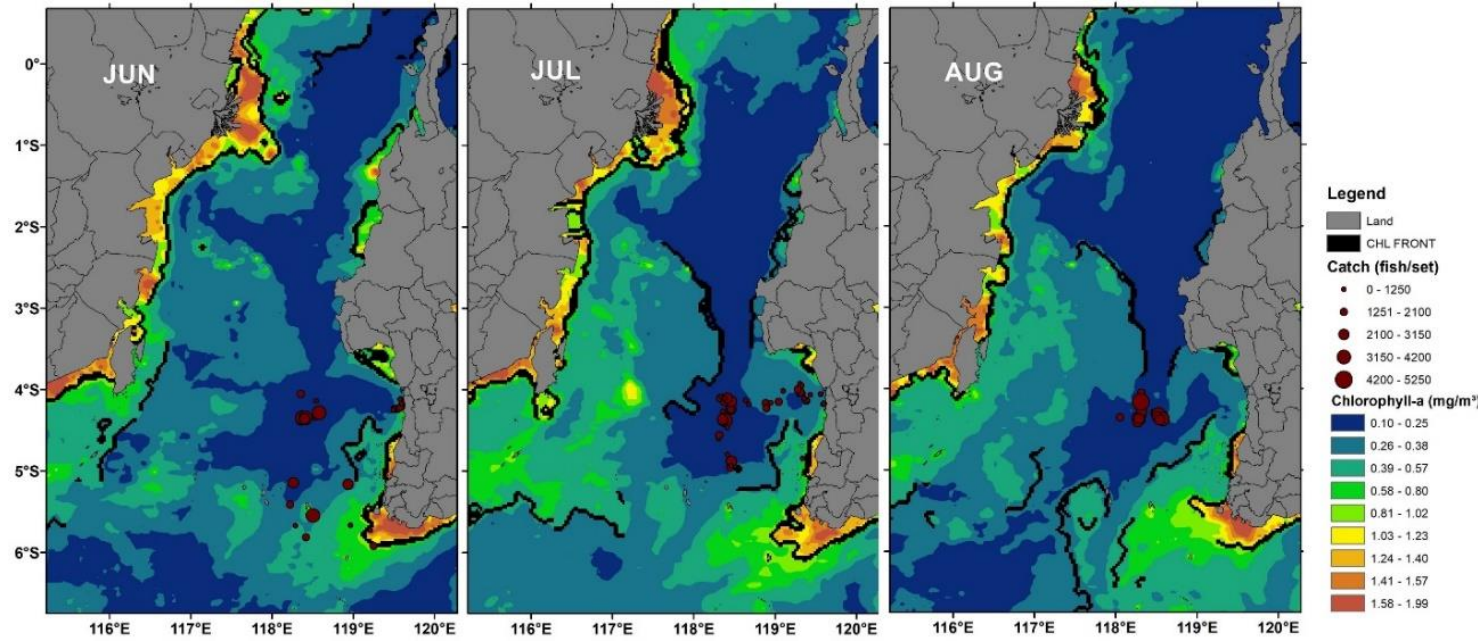

Figure 2. Chlorophyll-a front detection overlain with skipjack tuna catches (shown as dots) from June to August 2019 in Makassar Strait.

Front detection is performed automatically using the SIED method by detecting the two different water mass characteristics. Before processing the chlorophyll-a data using the SIED algorithm, the chlorophyll-a concentration value that has the floating-point format must be converted to an integer value by multiplying each pixel of the chlorophyll-a concentration value by the number 100. It's due to adjusting the format data which can be processed by the SIED algorithm in Marine Geospatial Ecology Tools (MGET) toolbox. Determination of the front area is done through the preparation of the map by combining the skipjack tuna catch data point with chlorophyll-a data which is then interpreted visually. If the front area is followed by an abundance of chlorophyll-a then the area is considered a potential area of fishing.

The chlorophyll-a front can be used as an indicator in determining the area of fishing ground. This is closely related to the availability of food resources in the waters [9]. The results of front detection using the SIED method showed that chlorophyll-a front was detected during the observation month from June to August 2019 and many fronts were detected in the southern part of Makassar Strait which is also the area of skipjack tuna fishing ground (Figure 2). In addition, it is also seen that many fronts are detected in coastal waters rather than in offshore areas for example in coastal parts along the island of Kalimantan and the central and southern parts of Sulawesi island.

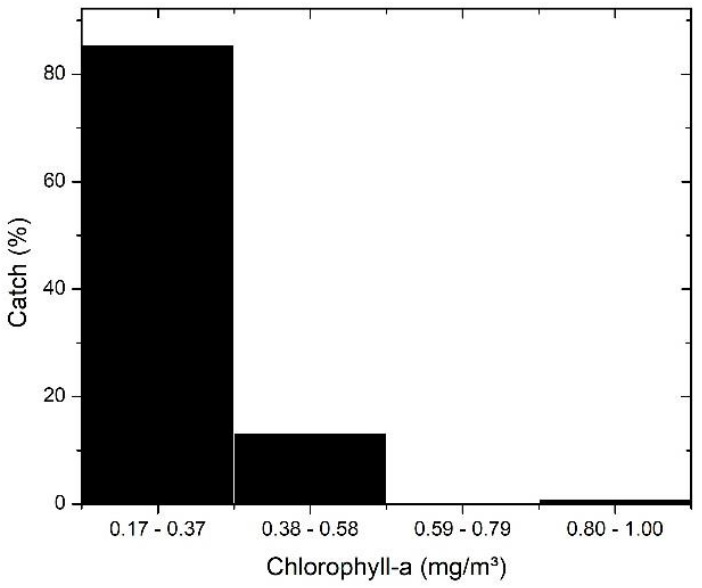

(a)

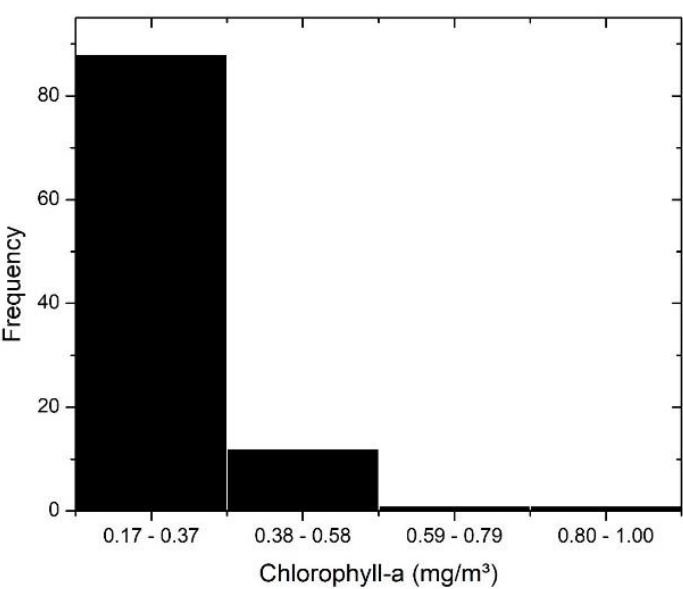

(b)

Figure 3. (a) Skipjack tuna catch data in relation to chlorophyll-a concentration, (b) The fishing frequency of skipjack tuna in relation to chlorophyll-a concentration.

Skipjack tuna distributed in the range of chlorophyll-a $0.17-1 \mathrm{mg} / \mathrm{m}^{3}$ with the highest catch is in the range of chlorophyll-a concentration $0.17-0.37 \mathrm{mg} / \mathrm{m}^{3}$ as much as $85.40 \%$ of the total catch, while the lowest catch is in the range of chlorophyll-a concentration of $0.59-0.79 \mathrm{mg} / \mathrm{m}^{3}$ which is as much as $0.39 \%$ of the total catch (Figure 3a). Based on the fishing frequency, the highest frequency is at the concentration value of chlorophyll-a $0.17-0.37 \mathrm{mg} / \mathrm{m}^{3}$, and the lowest frequency is in the range of chlorophyll-a concentration $0.59-0.79 \mathrm{mg} / \mathrm{m}^{3}$ (Figure $3 \mathrm{~b}$ ). 


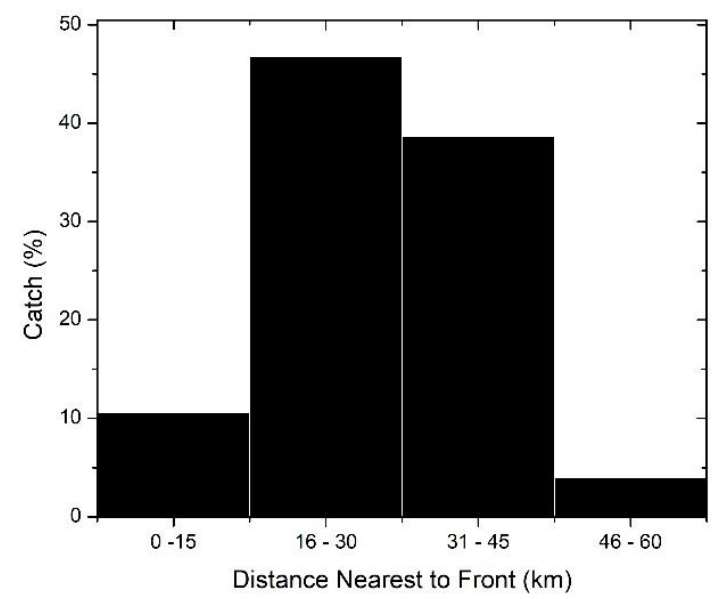

Figure 4. The histogram relationship between chlorophyll-a front distance and skipjack tuna catch from June to August 2019 in Makassar Strait.

The closest distance of chlorophyll-a front to the skipjack tuna catches in Makassar Strait based on front detection map with SIED method showed that the skipjack tuna occupied in the area of the distance nearest to the front in the range of $0-60 \mathrm{~km}$ (Figure 4). The highest catch is in the range of $16-30 \mathrm{~km}$ with a catch of $46.73 \%$ from the total catch, while the lowest catch is in the range of $46-60$ $\mathrm{km}$ from the front area with a catch of $3.97 \%$ of the total catch.

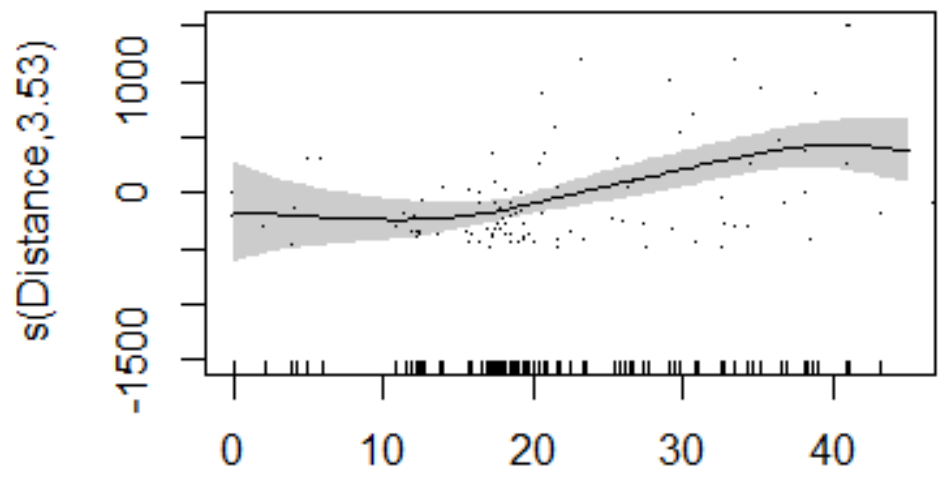

\section{Distance}

Figure 5. The generalized additive model derived the effect of chlorophyll-a front distance $(\mathrm{km})$ with skipjack tuna catches

Based on GAM analysis, the relationship of chlorophyll-a front distance to skipjack tuna catches is the skipjack tends to be high at a distance of $15-20 \mathrm{~km}$ from the closest distance to the front. This is because the front area is a fertile area of food sources for small pelagic fish that will certainly invite the large pelagic fish closer to the area $[9,10]$. Another result showed that skipjack tuna catch is relatively higher at a distance of 0-10 km from the area of the chlorophyll-a front in the Bone Gulf, Indonesia [11]. 
Table 1. GAM analysis model

\begin{tabular}{|c|c|c|c|c|c|}
\hline Variable & Edf & Ref.df & $\mathrm{F}$ & $\mathrm{p}$-value & \\
\hline $\mathrm{S}$ (Distance) & 3.535 & 4.352 & 4.98 & 0.000808 & $* * *$ \\
\hline
\end{tabular}

The significance of this study shows that there is a significant relationship $(\mathrm{p}<0.001)$ between the skipjack tuna catch and the closest distance of fishing ground to chlorophyll-a front (Table 1). This indicates that the chlorophyll-a front parameter has a significant effect on the skipjack tuna catch in Makassar Strait.

\section{CONCLUSION}

The results of chlorophyll-a front detection using the SIED method showed that chlorophyll-a front was widely detected in the southern waters of the Makassar Strait and in general close to the area of skipjack tuna catch. Gam's analysis of the closest chlorophyll-a front distance to the skipjack tuna catches showed that the skipjack tuna are relatively higher at a distance of $15-20 \mathrm{~km}$.

\section{ACKNOWLEDGMENT}

The authors would like to thank the skipjack hunter team for supporting the fishery data of skipjack tuna catch and fishing ground positions in the study area. We also like to thank the NASA Ocean Color website (https://oceancolor.gsfc.nasa.gov/) for providing the oceanography data set especially sea surface temperature and chlorophyll-a.

\section{REFERENCE}

[1] Gordon, A. L. (2005). Oceanography Of The Indonesian Seas And Their Throughflow. Oceanography, 18(Spl.Iss. 4), 15-27. Https://Doi.Org/10.5670/Oceanog.2005.01

[2] Zainuddin, M., Saitoh, K., \& Saitoh, S. (2011). Application Of Satellite Microwave Remote Sensing Data To. 8, 49-56.

[3] Simbolon, D., \& Tadjuddah, M. (2008). Pendugaan Front Dan Upwelling Melalui Interpretasi Citra Suhu Permukaan Laut Dan Clorofil-A Di Perairan Wakatobi Sulawesi Tenggara Forcasting Of Front And Upwelling By The Sea Surface Temperature And Chlorophyl-A Interpretation In Wakatobi Waters , Southe. Xvii(3), 362-371.

[4] Kirby, D. S., Fiksen, Ø., \& Hart, P. J. B. (2000). A Dynamic Optimisation Model For The Behaviour Of Tunas At Ocean Fronts. Fisheries Oceanography, 9(4), 328342. Https://Doi.Org/10.1046/J.1365-2419.2000.00144.X

[5] Zainuddin, M., Nelwan, A., Farhum, S. A., \& Hajar, M. A. I. (2014). Characterizing Potential Fishing Zone Of Skipjack Tuna During The Southeast Monsoon In The Bone Bay-Flores Sea Using Remotely Sensed Oceanographic Data. April. Https://Doi.Org/10.4236/Ijg.2013.41a023

[6] Cayula, J. F., \& Cornillon, P. (1992). Edge Detection Algorithm For Sst Images. In Journal Of Atmospheric \& Oceanic Technology. (Vol. 9, Issue 1, Pp. 67-80). Https://Doi.Org/10.1175/1520-0426(1992)009<0067:Edafsi>2.0.Co;2

[7] Mustasim, Zanuddin, M., Safruddin, \& Sutono, D. Oceanographic Parameter Perefence (SPL and Chlorophyll-a) on Skipjack Tuna Catches in Misool Island and Fakfak Water. Airaha Journal. Vol. VIII(1) June 2019, 16-23.

[8] Zainuddin, M., Safruddin, Farhum, S. A., Ridwan, M., Putri, A. R. S., Hidayat, R. (2019). The Effect Of Oceanographic Factors On Skipjack Tuna Fad Vs Free School Catch in The Bone Bay, Indonesia. 123-130.

[9] Polovina, J. J., Howell, E., Kobayashi, D. R., \& Seki, M. P. (2001). The Transition Zone Chlorophyll Front, A Dynamic Global Feature Defining Migration And Forage Habitat For Marine Resources. Progress In Oceanography, 49(1-4), 469-483. Https://Doi.Org/10.1016/S0079-6611(01)00036-2

[10] Zainuddin, M., Farhum, A., Safruddin, S., Selamat, M. B., Sudirman, S., Nurdin, N., Syamsuddin, M., Ridwan, M., \& Saitoh, I. (2017). Detection Of Pelagic Habitat Hotspots For Skipjack Tuna In The Gulf Of Bone-Flores Sea, Southwestern Coral Triangle Tuna, Indonesia. 1-19.

[11] Hidayat, R., Zainuddin, M., \& Putri, A. R. S. (2019). Skipjack Tuna (Katsuwonus Pelamis) Catches In Relation To Chlorophyll- A Front In Bone Gulf During The Southeast Monsoon. 12(1), 209-218.

\section{AUTHORS}

First Author - Andi Risda Fitrianti Abudarda, Postgraduate Student of Fisheries Science, Faculty of Marine Science and Fisheries, Hasanuddin University, Indonesia. arisda65@gmail.com

Second Author - Mukti Zainuddin. Faculty of Marine Science and Fisheries, Hasanuddin University, Indonesia.

Third Author - Safruddin. Faculty of Marine Science and Fisheries, Hasanuddin University, Indonesia.

Correspondence Author - Andi Risda Fitrianti Abudarda. Postgraduate Student of Fisheries Science, Faculty of Marine Science and Fisheries, Hasanuddin University, Indonesia. arisda65@gmail.com 